\title{
Music and Art in Tareque and Catherine Masud's Film Muktir Gaan
}

\author{
By Rehnuma Sazzad
}

Spring 2013 Issue of KINEMA

\section{THE ROLE OF MUSIC AND ART IN TAREQUE AND CATHERINE MASUD'S FILM MUKTIR GAAN}

The Bangladeshi documentary Muktir Gaan (Song of Freedom)(1) by Tareque $\&$ Catherine Masud earned international recognition as did the directors' autobiographical Maatir Moyna (Clay Bird). ${ }^{(2)}$ The statement of the juries of Film South Asia '97 reads: 'For its powerful recreation of the euphoria of an event long forgotten by the world, the Jury would like to make a Special Mention of the film Muktir Gaan by Tareque and Catherine Masud.'(3) The euphoria of victory brought by Bangladesh's Liberation War against Pakistan in 1971 was an event of profound political significance. The author aims to shed light on the form of realism the documentary presents, which is enhanced by its remarkable use of music and cinematic techniques. The discussion also brings out the question of cultural resistance of the Bengalis in what was East Pakistan, struggling against the authority of West Pakistan during the 1970s and prior to that period.

The documentary came into being as a result of a chain of coincidences. Through a chance encounter that led to the directors' discovery of Tariq Ali, a member of an artistic group (seen in Figure 1) that took part in the war through music and art, the Masuds were encouraged to search for Lear Levin, the American filmmaker and photographer whose footage the documentary is based on. Interestingly enough, one of Tareque Masud's cousins, Mahmoodur Rahman (Benu), was a friend of Ali and also part of the ensemble to which Levin got attached in 1971. Consequently, when the musical troupe travelled around the refugee camps, border areas, and the liberated zones to sing their songs of love for the homeland in order to inspire the guerrilla Freedom Fighters, the refugees, and the ordinary villagers who had stayed at home, Levin's camera was their constant companion. Twenty years later, the directors tracked the filmmaker down in New York as a result of their union with Ali. Fortunately Levin had a large stock of the war footage, which he allowed the directors to use for their film.

Despite waiting several years to find someone to fund his project to create a Robert Flaherty-style documentary using the footage, Levin preserved it with much care. Like Flaherty, Levin wanted to create an intimate record of the spirit of a people at a particular time in history. The Masuds achieved a similar effect but with a musical richness that requires a nuanced analysis in order for viewers to realize that the coincidences mentioned above could not have happened without the pivotal role played by Bengali culture during the Liberation War of Bangladesh.

Let us then take a look at the cultural troupe Bangladesh Mukti Shangrami Shilpi Shangstha (Bangladesh Freedom Fighter Artistes Association), through whose eyes the nine-month war is viewed. One of their voice-soldiers, Tariq Ali, introduces them as a 'group of cultural activists, who sing songs of the freedom struggle, to keep the people's morale high'.(4) Their courageous role is comprehensible through the very first music that connects them with the broader canvas of the war and makes us realize the importance of their resistance even before Ali articulates it. As the song 'From land to land we travel/ singing of your travail...' addressed to the occupied homeland floats around, there establishes a powerful sense of solidarity between the troupe and the common people, whose massive exodus is seen on the screen. The song is brief, has only a few words, and quickly recedes into the background as Ali's voiceover starts. But it is very effective in setting the tone of the documentary, which is that of a whole nation's struggle for freedom.

However, because of the prominence of the young and educated group in the documentary, Naeem Mohaiemen interprets the Liberation War it represents as a saga of the middle class, 'the only class that was truly "liberated" in 1971.(5) Contrary to the Mohaiemen's view, the following discussion shows that the war was never that of a particular group or class; it was genuinely fought by all the sections of the nation. Interestingly, Mohaiemen points out that 'the presence of a large number of Hindu performers in the cultural troupe $^{(6)}$ is ironical, since the secular spirit of the struggle was compromised in the post-independence 
Bangladesh. Regrettably, he is right about the downplaying of the spirit later on. However, one must stress that Mohaiemen's observation of the fact that the predominant Hindu presence in the film 'seems to have escaped audiences at most screenings' ${ }^{(7)}$ of the documentary inside the country speaks volume about the way the humanist ethos of the Liberation War is inscribed in the common people's psyche.

In any case, Mohaiemen is quite drawn to the idea that

[t]he subtext that is not explored in the film but is nevertheless clearly present on screen, are the class differences among the Bengali refugees and freedom fighters. The troupe members are, for the most part, from middle-class backgrounds. Yet, here in the course of the film, they mix with village refugees, farmers and foot soldiers. There is some awkwardness in these interactions, as when the troupe embraces a group of soldiers at a liberated zone. In these few moments, one of the fundamental contradictions of the war effort is visible on screen. ${ }^{(8)}$

It is true that the war was spearheaded by the middle class. But it was not merely their war; there was a general support for the guerrillas and the artistes, without which the war simply could not have been won. For example, Mohaiemen fails to notice that just before entering the liberated zone, the artistes stop their truck and have some food on banana leaves in an open field, as they intently listen to a villager's account of the guerrillas' killing of a Pakistani soldier and their burial of him. The united spirit that pervades the rustic teller and his urbane listeners evades Mohaiemen's eyes. Also, one does not see 'the awkwardness' he finds in the artistes' embrace of the guerrillas in the liberated zone. The spontaneity of the event should be evident from the shot below:

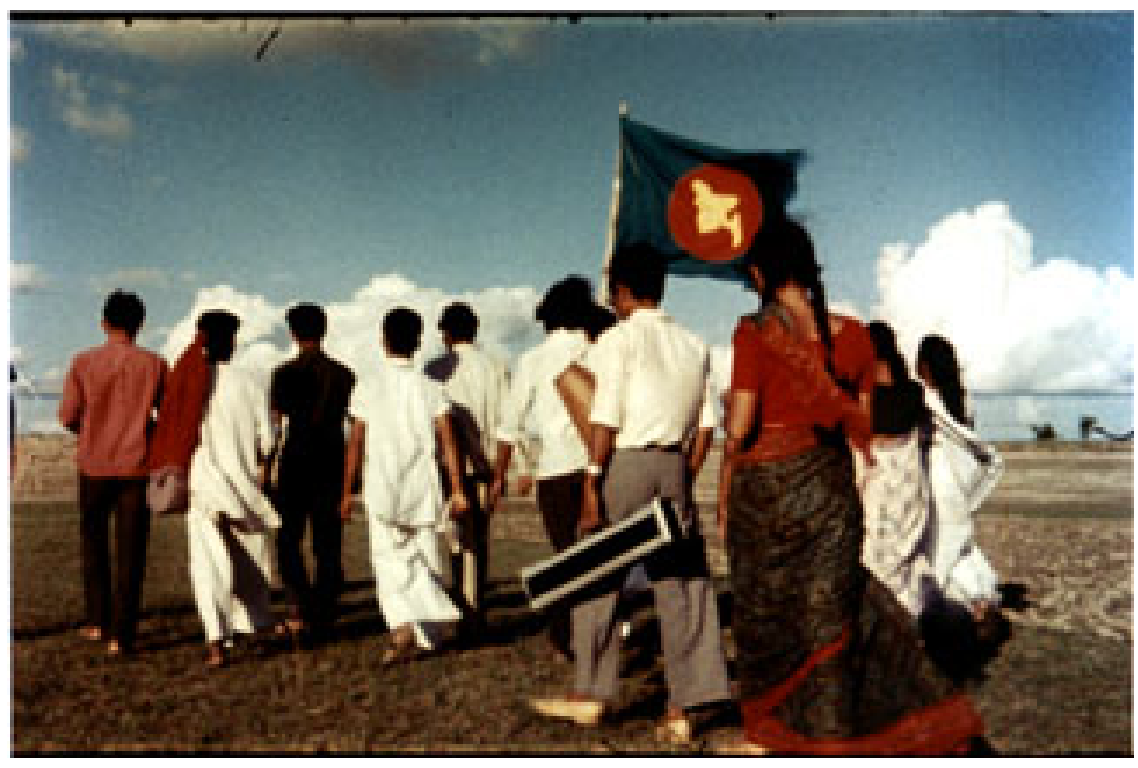

Figure 1: Figure 1

At this point, it must mentioned that when the artistes entered the free zone, a small unoccupied part of the motherland, they were overwhelmed with pain and joy. Some became emotional, clutching the mud from the marshy land or spreading it on the forehead as if it was real gold. As they started to walk on the land singing, we can see how an unbounded sky and a vast plain welcomed them in their midst, as if by providing them with protection and reassurance:

The song they were singing at the time (it became Bangladesh's national anthem after independence) is significant in this context. It was heard in the background when they were en route to the free zone by boat. The postcard-like picture of their journey mixed with the song not only highlights the beauty of the land but also emphasizes the connection between mother Bengal and her children:

In any event, the artistes' song continued: 'Your words are sweet/ as honey to my ears - ' This is where the chorus became discordant; because the ordinary people of the rural area had joined their voices with the 


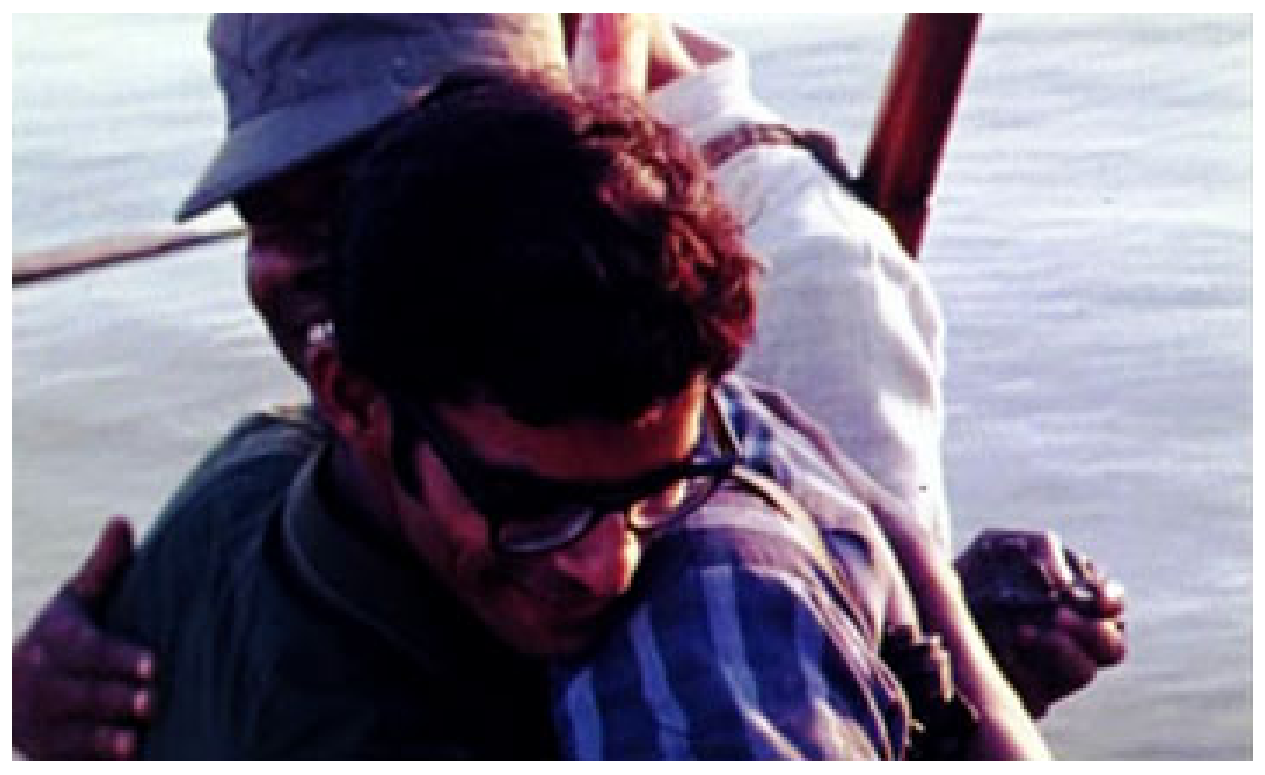

Figure 2: Figure 2

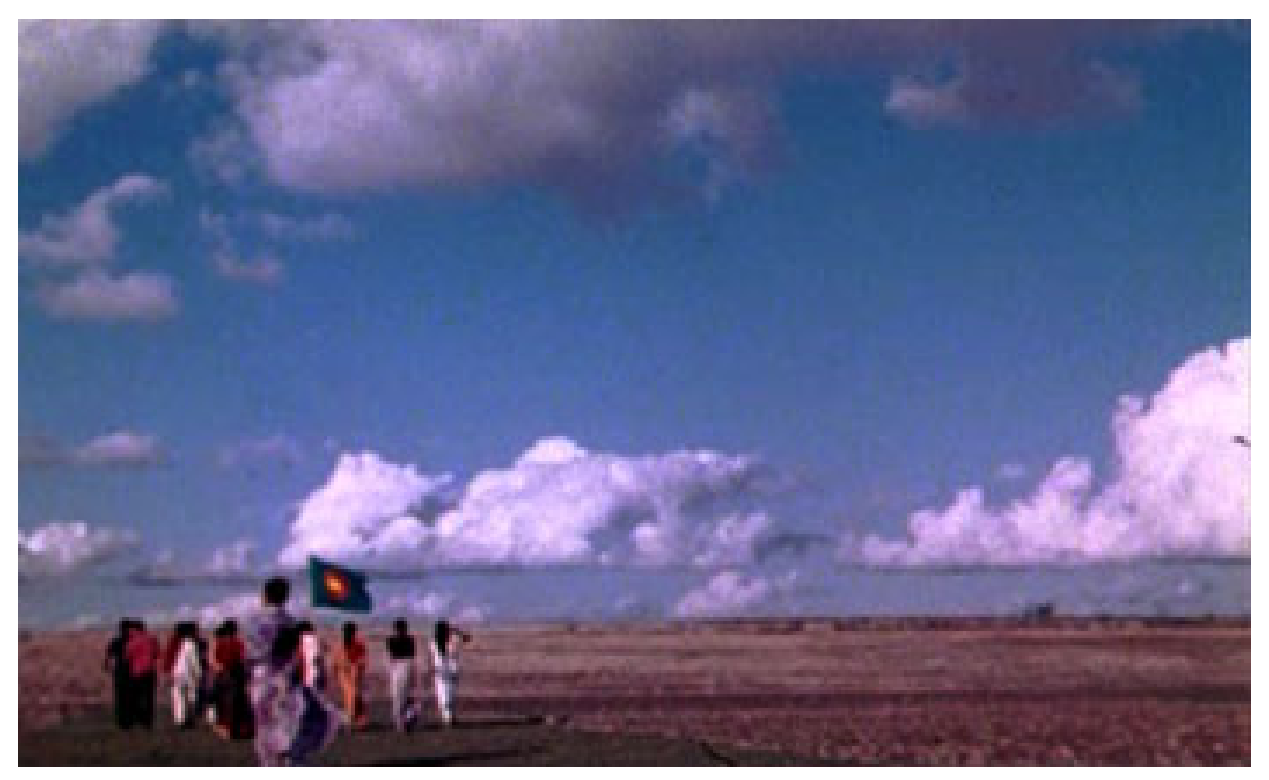

Figure 3: Figure 3 
artistes by then. Notwithstanding the dissonance, the harmony among all came alive.

Perceivably, the Bengali artistes' resourcefulness, commitment and resilience during the war earned the respect of the photographer, who had fallen in love with the land. This explains why the war documentary is filled with shots that could be only described as poetic, transforming the documentary into a remarkable piece of art. The still below, for example, captures the beauty of the rainy season in a village, which the troupe visited at one point in their constant travel:

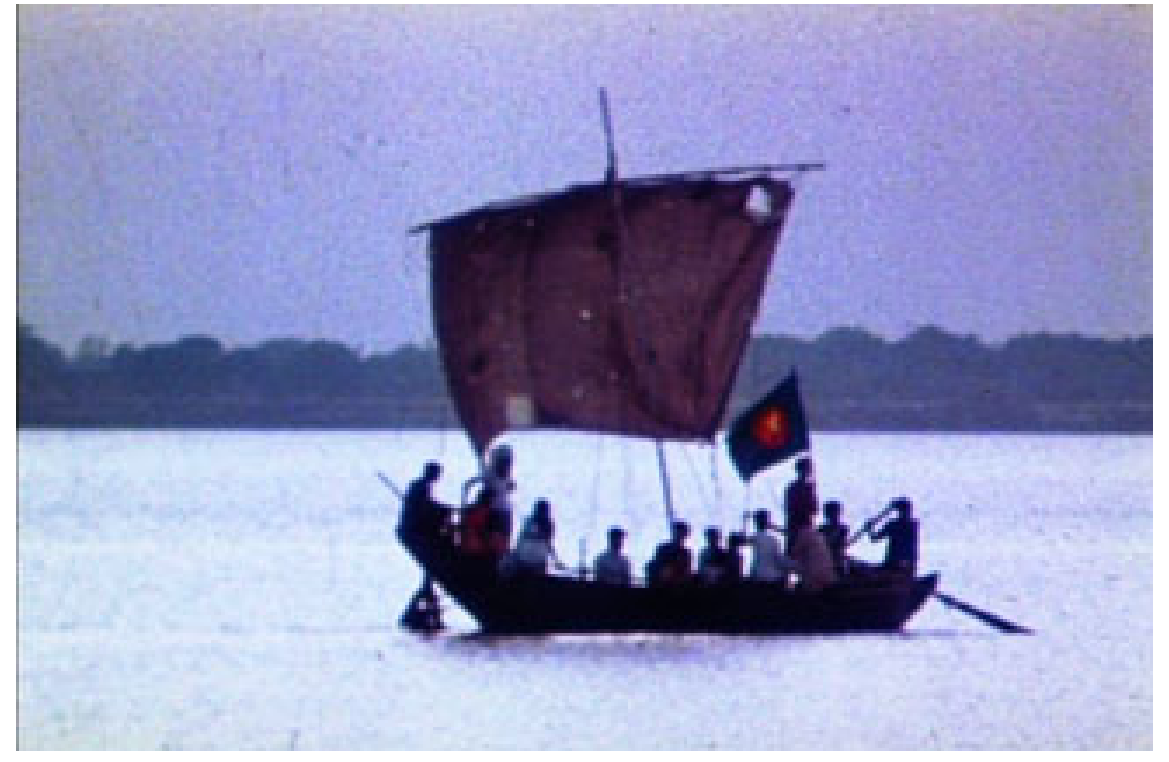

Figure 4: Figure 4

Befittingly, the songs in the documentary accompanied by the images strengthen the facts of the silent endurance of the land and its inhabitants. This is illustrated by the next image as well, which appears just after a song relaying the destructions of the war. The song grieves over the wretched condition of the land, which is vivified by the footage of a herd of vultures circling round some corpses. Soon after the song ends, though, the serene picture below spreads over the screen as if to soothe the effects of the frenzy of fire and blood all around:

A similar shot appearing further down enables viewers to see once again how the people are at one with nature. It feels as if the tall tree in the picture is spreading its arms around the truck with which the troupe wanders the border areas, the refugee camps and the free zones. It is as if the tree, like the sky and the field above, is reassuring the group, supporting its fortitude, and affectionately putting a marquee over its head. It is as if nature was helping the people to sustain their courage and conviction in their existential struggle against the aggression of a powerful military.

For this reason, it should be emphasised that the1971 war was a saga of resistance in which the Bengali people took part due to their love for their motherland and their humanist cultural values. Significantly, the deep devotion to that period of time creates a bond that connects the photographer, the artistes and the directors as well. The depth of their attachment to 1971 crosses the boundary of time. It was how the directors came to rediscover the long-lost connections to the war struggle, which was crucial for the birth of the documentary. It should be noted that the upheaval Levin's camera recorded was youth-led. As he was in his youth at that time, he became completely seized by the general spirit of the resistance. Understandably, therefore, the admiration he felt for the aspirant youth and their unborn nation made him preserve the footage for two decades.

The Masuds were led to him, because they dreamt of recreating the spirit of 1971 for the present day youth in Bangladesh. Tareque Masud puts this in perspective: '"Our main aim is to present some incidents of the liberation war before the young people. We hope that they will be able to realise that the war of our 


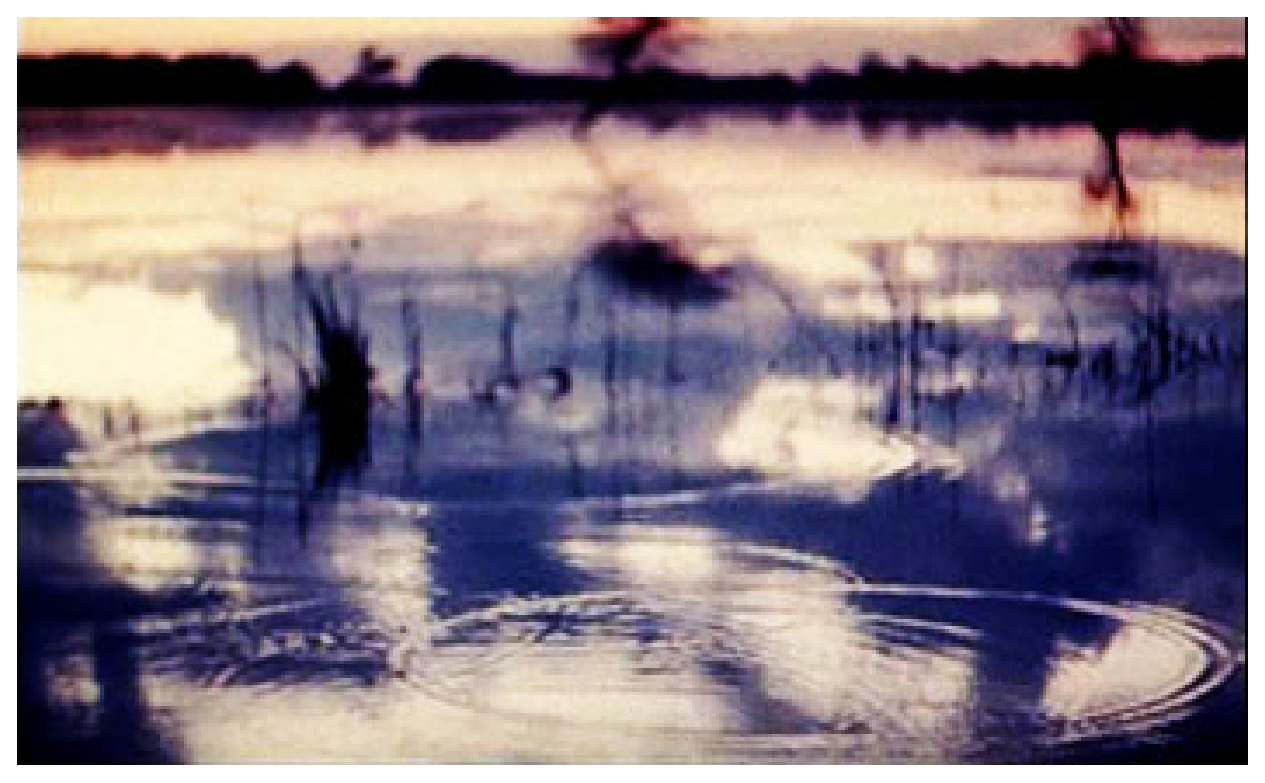

Figure 5: Figure 5

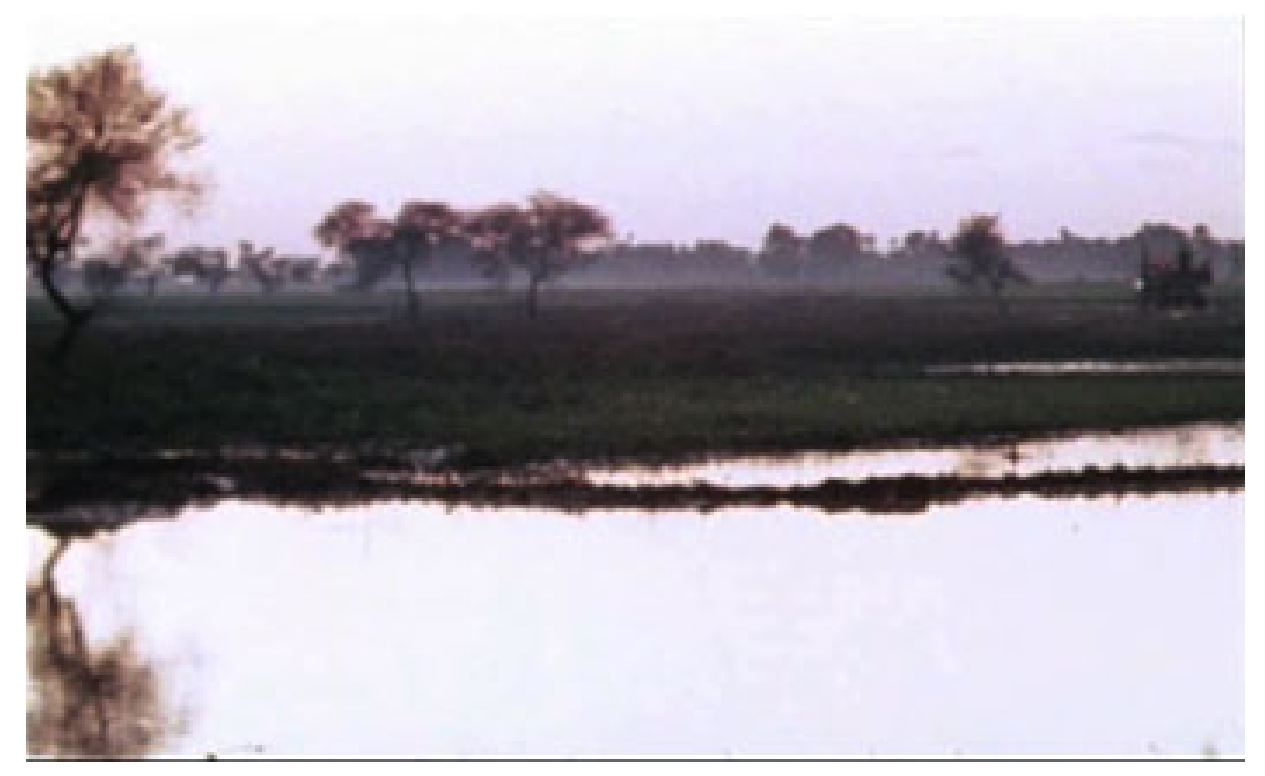

Figure 6: Figure 6 
independence was a result of people's united effort"'(9) (emphasis added). Perceivably, a Benu or a Tariq Ali was not a rare incident at all. Rather, their presence signifies the general yearning for freedom among the Bengalis in 1971. Therefore, Benu and Ali are not simply class representatives either.

In any case, Nayanika Mookherjee argues that the visualisation of the rural and fertile landscape as 'mother' in the documentary supports the essential role of women in Bangladesh. ${ }^{(10)}$ After independence, the middle class played a key role in reconciling the sexual violence against women during the war with the prevalent images of 'women as mother' and 'women as nature'. Mookherjee goes so far as to claim that

Muktir Gaan can be seen to be a critique of the cocooned, luxurious romanticism and sentimentality of the middle class about the war and the nation. Most of the young men and women came from upper-middle-class backgrounds and spent their time during the war in Calcutta and India, far away from the ravages of the war. However, its immense popularity in the 1990s reinscribes the image of woman within the folds of the mother nation and of middle-class aesthetics. ${ }^{(11)}$

The following discussion will attempt to show that the Song of Freedom is anything but a critique of a withdrawn middle class, since the artistes represent neither the alleged luxury and sentimentality nor the sheltered existence. In fact, one can safely assert that it is a gross overstatement that they were living comfortably. In truth, the ravages of the war fuelled their patriotic-humanist spirit, as the discussion below will highlight. The important point is that the troupe performed under no illusion about its insecure state and future. The artistes had no guarantee that liberation would be achieved and their class would eventually take the helm of the newly independent country.

If anything, as Mohaiemen noted above, the secular ideals they stood up for are thwarted in the country today. In addition, the documentary never simply reinscribes womanhood within the mother nation; rather, it harmonizes the images of the land, nation, and mother within a universally humanist narrative. More vitally, it presents women as voice-soldiers who are as much active on the frontline as their male peers. If the violence on women during the war was later suppressed by taking recourse to the image of the nation as mother, Levin's poetic shots and the artistes' patriotic music could only be at most superficially blamed for that.

Indeed, the documentary suggests that opposition to Pakistan was pervasive, due to the Bengalis' wounded pride in their ancient land and culture. From this perspective, it feels natural that the Masuds decided to give the documentary the musical form they did, for the Bengalis' dream of freedom found expression in the artistes' singing, painting and puppet shows that intersperse the documentary. It shows how creativity sustained the cultural squad, reached their inner being, and uplifted them. Consequently, their cultural message bolstered the people they visited with hope.

Mitu Varma describes the documentary as one that 'touched many a Bangladeshi's heart', adding that Muktir Gaan 'has the distinction of being probably the most-watched documentary film in South Asian history, running to full houses in commercial cinema halls and to overflowing crowds in makeshift rural screenings...'(12) Why it has been so well-received both in the cities and the rural areas tells us anew about the united force of the Liberation War. In fact, through the art and music in the documentary, we realize that the millennia-old riverine plain of Bengal is historically home to many religions, peoples and practices. Naturally, the culture of the land exudes humanistic values. Therefore, when the Bengalis were considered by the Pakistani rulers as a lesser people, since their 'practice of Islam was too Bengali (hence too Hinduized/ Indianized) ${ }^{\prime(13)}$, they resisted with the full force of what they held most dear: their culture. Thus, the songs and music of the documentary narrate the tale of a people's resistance, responding to political aggression with their passion for creativity and life.

This brings us back to the starting song of the documentary. We see the images of mass exodus of the Bengalis after the Pakistani military's crackdown before the music begins, its lyrics singing of the plight of the people in the occupied land. The accompanying footage shows barefoot people leaving behind almost all they treasure, carrying nothing but some home utensils, bundles and boxes. The United Nations debate about the number of the refugees is heard in the background at the same time. The juxtaposition of the image and the broadcast makes us realize that the issue is not the numbers, though it turned out to be vast.

The main issue is the West Pakistani government's dehumanisation of the Bengalis, which is epitomised in 
one of the shots, where a paralysed refugee tries to crawl in the mud to keep pace with the procession. When the voice over introduces the troupe as 'refugees' as well, a clear identification between the crawler, marchers, and cart-driven commoners and the urban group is established. Hence, their singing of these people's sorrows with their 'eyes flowing with tears', as they sit on a truck that becomes their virtual home, which constantly travels through 'cities, fields and forests', does not sound uninvolved at all. Rather, it complements the documentary's intended realism depicting the march of millions, who are driven out of their 'homes, hopes and dreams.'

Another aspect of the musical narrative of the war has to be noted too. It gives prominence to a soulful slogan of the war, 'Joy Bangla (Victory to Bengal)', by emphasising the land and language based identity of the people. Rather than the artistes' religious or gender differences, the starting song emphasises their existence as an endangered group. Let us look at the names of the members of the group as they are introduced to us.

Mahmoodur Rahman Benu, our group leader, his wife, Shaheen... two sisters, Naila Zaman and

Lubna Marium... Swapan Chowdhury... Bipul Bhattacharya... Sharmeen Murshid... Debabrata

Chowdhury... Lata Chowdhury... Dulal Chandra Shil... and me, Tariq Ali. And many others, directly or indirectly involved with out troupe...

The names are connected by ellipsis, which could be filled in by their different identities. However, the starting song nullifies the need through the distinct focus:

We shall weep at your grief, Mother, and make others weep too.

Our lives we have staked for you,

for you we will readily die.

Simply put, they are all children of mother Bengal, who have pawned their dearest possession, their life, to earn her freedom. Once again, we can see that the war is not fought on any narrow notions of caste, creed or class.

Their singing manifests this again and again. For example, the troupe sings in a guerrilla training camp at a border zone, where thousands of ordinary young men who have enlisted in the war listen to them. The song urges:

Labourers and farmers,

O comrades of Bengal -

Brothers, what have you to fear?

You are steering the nation's wheel.

Victory will be yours.

The repetitive use of the word 'comrade' puts them all on the same platform; they are the defenders of the nation's freedom, fighting the same fight for existence. The united spirit is tangible once more when the troupe braves the rainy reason and goes round a village forming a big procession joined by a large number of villagers. The artistes walk around playing their instruments and singing:

We are the invincible youth

of Mother Bengal -

Tireless and strong,

resolute in crises.

Another chorus that the troupe delivers in one of the camps of the Freedom Fighters reflects the humanistic ethos of the struggle:

The people's fight is on, our struggle shall go on -

With bright honour we fight

for the right to life and freedom...

Let the nights be seamless -

We, the charioteers of Time, shall

spend days and nights sleepless. 
The song succinctly puts forward the mantra with which the war was fought by the guerrillas, the artistes, and the ordinary people. The enthusiasm for fighting was universal, because the song says it was for 'life and freedom' and 'peace and well-being'. Since the 'pilgrims of destiny' felt in their hearts that they were fighting for truth, justice, and human dignity, '[t]he people's fight' never needed any propaganda. Time determined the common duty of the people and their resolve was fiery and final. The artistes emphasise their steadfastness:

Though the way is long and perilous, we still have countless companions.

And millions to share our suffering.

Naturally, everyone's dream of freedom fills the air with hope while the song goes on.

The footage accompanying the song illustrates this beautifully. The picture here renders visible the nobleness of the cause felt by the artistes and the guerrillas. The brightened eyes of a Freedom Fighter listening to the song, show how animated he feels. Later on, he urges others to join in the chorus by the gesture of his hand. Indeed, the song instantly ignites them all, and we see another Freedom Fighter in the scene who clutches his rifle, sings along, and moves his hand to the beat of the song. Such was the power of the music, motivating the people to give up their lives in the fight, sometimes without a second thought:

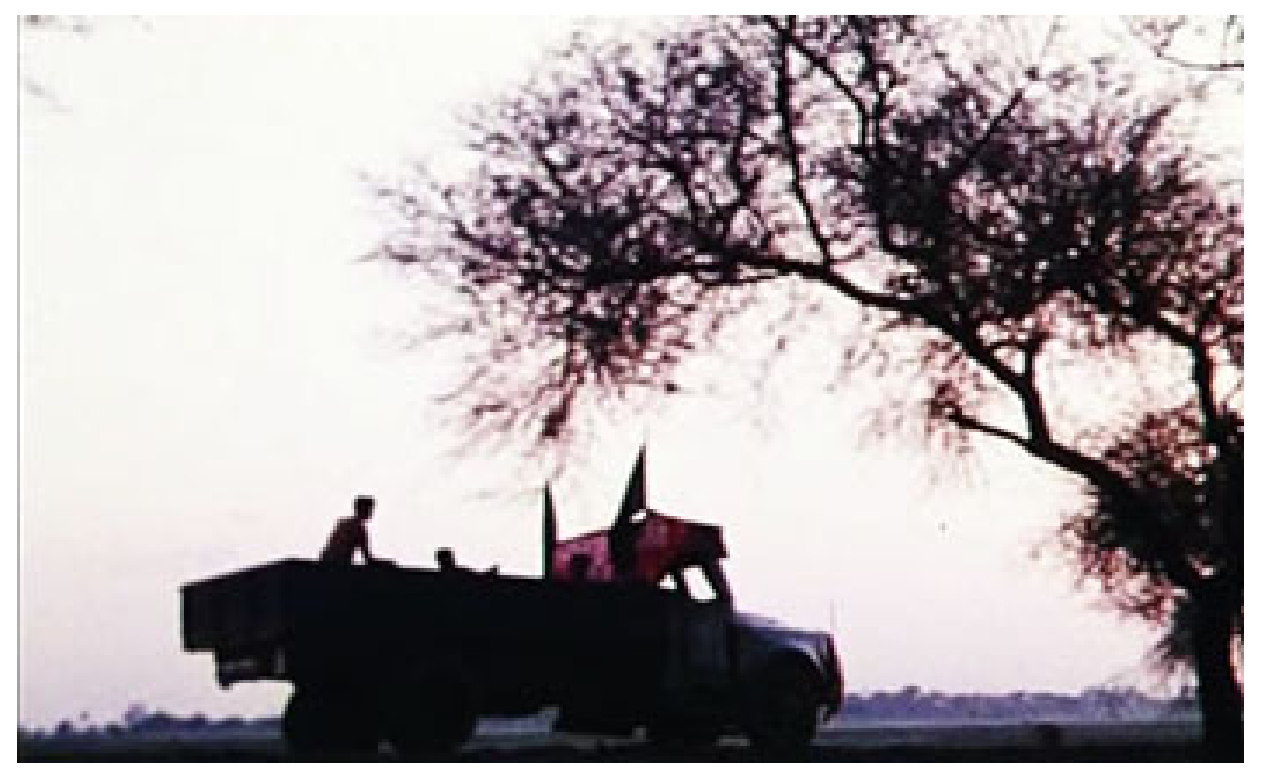

Figure 7: Figure 7

The South African philosopher Leo Kuper records the slaughter of the Bengalis on the $25^{\text {th }}$ of March as a scandalous incident triggering their armed opposition against the Pakistani occupation forces. This was the historical moment when the struggle for independence formally started. Referring to the round table meeting over equal power sharing in the Eastern and the Western parts of Pakistan at that time, he writes that 'during the course of the negotiations, the government [representing the West] was in fact mobilizing its military forces in the East, and on 25 March, 1971, it struck with devastating force.(14)

The whole attack was uncalled for and what followed was plain and simple carnage. One would have liked the Masuds to include some images of the genocide carried out on the night, for it sealed the ground of separation between the two absurdly joined parts of Pakistan. However, Tariq Ali's voice-over does mention that the genocide of the Bengalis (on the $25^{\text {th }}$ and after) led them to the armed struggle against Pakistan. For him, the incessant killing was 'nothing less than a Holocaust.' Clearly, the armed struggle of the Bengalis was an urgent form of self-defence, which explains the spontaneous participation in the war.

At any rate, given its historical nature, the documentary had to record the rueful waste of human lives during the war. In doing so, it combined art and history with remarkable expertise. Indeed, the dominant 
presence of music throughout the documentary saves it from becoming a completely black canvas portraying the horrors of the war alone.An example of the bloodbath is depicted here:

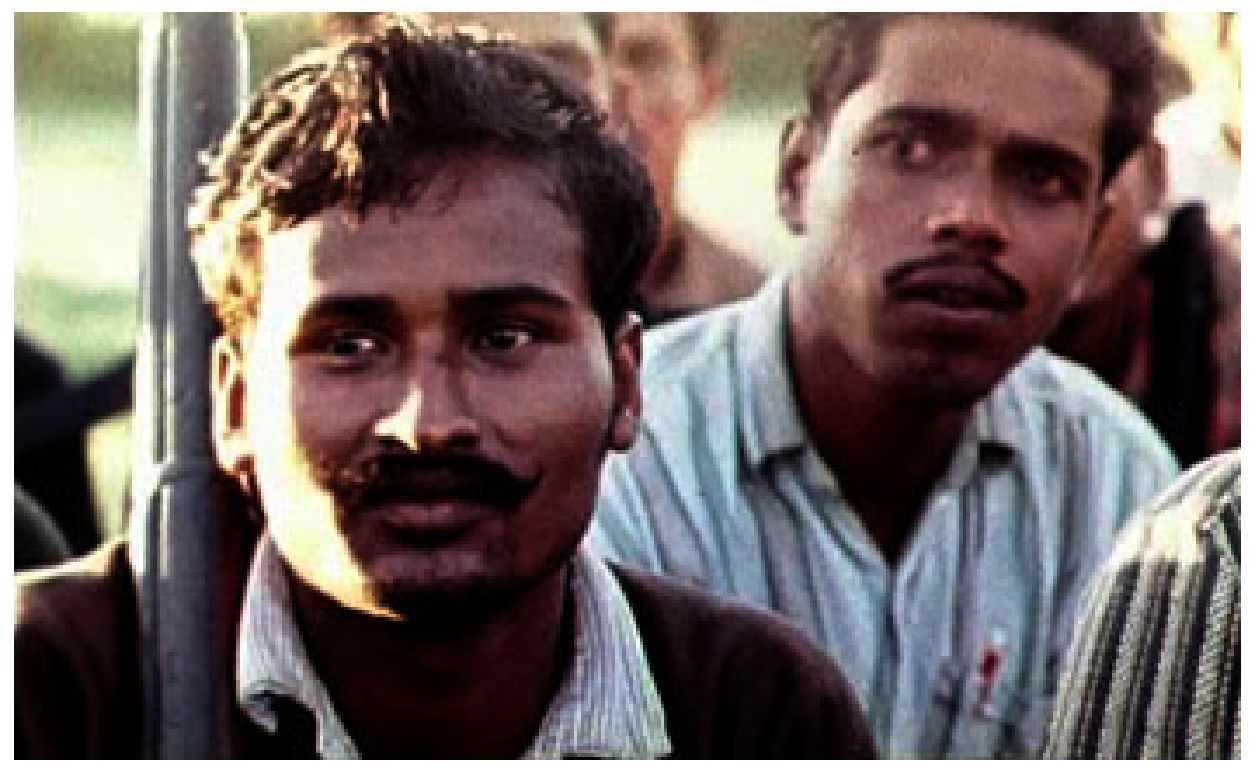

Figure 8: Figure 8

Understandably, the pictures of atrocities are successfully conjoined with powerful songs. The song below, for example, is heard when the footage of the violence is shown. As the song goes on, an elderly lady describes her sufferings to two of the members of the troupe; one of them holds her hand tight, both cry with her, and the open voice of their fellow artiste fills the surroundings. The juxtaposition of the beauty of Bengal the song laments for with the widespread brutalities on the screen becomes poignant amidst the bard-like rendering:

My heart cries out in despair

to sing the song of Bangladesh.

This land of Bengal, spun from gold, now is soaked with blood.

As the footage includes blood-soaked bodies, burnt houses and wailing women, the epic dimension of the losses is also established through the artiste's voice:

Even the moon and stars shed tears

seeing such human misery.

Ours is a land of rivers,

shrouded in abundant green...

Its rivers - Padma, Megna, Jamuna

are flowing today blood.

The weight of misery increases, when the blood flows from the near and dear ones. This is the case with the next incident the song describes and the screen portrays:

My dear sweet boy,

lies dead by the road...

a herd of vultures

feeding on his corpse -

It is one of those moments when absurdity takes over normalcy, since the young man's wound is a source of excitement for a herd of vultures. When the song finishes, the superimposition of the fading faces of the listeners on a full screen shot of the tree under which they gathered to listen to the song, brings this 
absurdity into a sharper focus. The shot seems to suggest how the unnaturalness of the events affects both the land and the people:

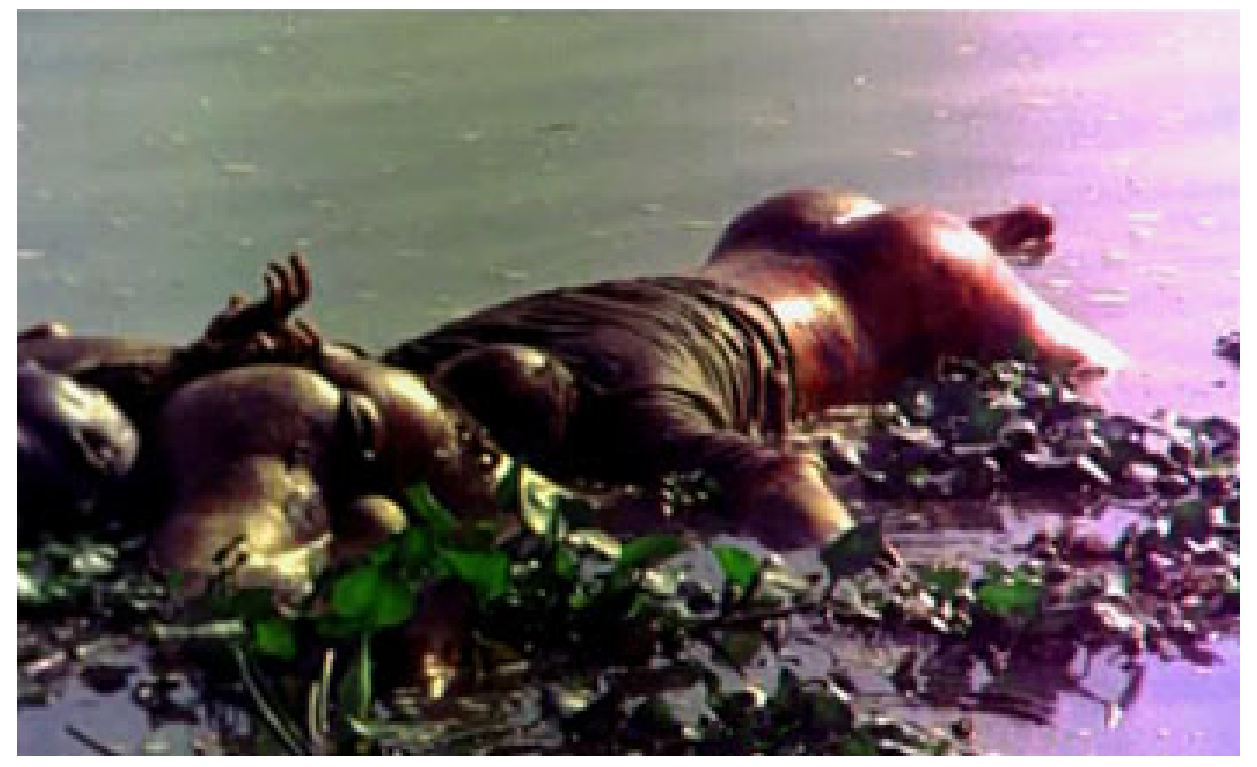

Figure 9: Figure 9

However, the documentary is not wholly a gory affair. Its record of the little things of life increases its humanist appeal. For instance, the warmth the refugees show to the artistes is heartening. Having experienced the tales of 'terror and pain', they live in camps that allow them to be 'no better off than animals'. And yet, when the troupe enters one of the refugee villages, the artistes are moved by their hospitality, which appears to be part of their everyday practice and they are keeping it up even under extreme hardship. In the same way, when we see that artiste Lubna Marium is cradling one of the emaciated refugee babies, we feel happy. Alongside the smiling faces of women and children in the refugee village, one of the most wonderful phenomena takes place when the hospitable family gives Ali their pet parrot because of his interest in the bird. Thus, the singers not only sing for the refugees but also establish a moving connection with them. Understandably, this is possible because they share the same plight of statelessness and uncertainty, as Ali emphasises by calling the bird a refugee like them all.

These small events create a powerful subtext of hope in the otherwise bleak documentary. We can consider another episode, where the sound of the boys' vocal exercise is parallelled with the girls' sharing of the war front news with each other, when the troupe stops after their truck breaks down. Naila Zaman draws Sharmeen Murshid's attention to an interesting scoop by saying, 'Did you see this? "We are tired, we want women and wine." This clarifies the different nature of the war the Pakistani army and the Bengali soldiers and guerrillas are fighting. For the former, the killing and destructions are part of their paid job after which they want entertainment in the form of more abuse to the occupied people.

For the latter, the war is to be free from the abuses. Hence, the artistes' struggle is to keep alive the fighting spirit among all. For them, the newspaper headline, 'Free Bangladesh by December', was a probability. For the Bangladeshi people today, it is fact. Their hope-filled struggle is what changed the possibility into reality. The flute playing refugee with his mellifluous tune and Swapan Chodhury with his beautiful sketches strengthen the same feeling. They also prove that cultural expressions are not solely class-based. The Masuds' successful depiction of the role of art in the day-to-day life during the war further enhances the main message of the documentary, which is that the Bengalis opposed the Pakistani aggression through their humanity and creativity.

The documentary also projects the puppet shows organized by the troupe as another form of cultural resistance. We see that the crowd in a village the group visits gathers to watch their show, where the puppet 
of an ordinary young man talks to that representing Yahya Khan, then president of Pakistan. Here is their conversation:

You can't fight with me alone! Call your men.

Oh! I can't find them - Where have they all gone...

All the killers are now roasting in the inferno.

What do you mean?

Have you heard about the freedom fighters?

Freedom Fighters? Are they around? Where?

$\cdots$

They're right in front of you!

I'm a Freedom Fighter too.

The use of the radio broadcast serves the same end. The incident where the troupe listens to Swadhin Bangla Betar Kendra (Free Bangladesh Radio), a radio station established in Calcutta by another group of exiled Bengali artistes who used to broadcast regular news, music and other cultural programs during the war, is significant. As the news stops and the radio starts to air a song, the troupe spontaneously joins in the chorus singing a song written by the Nobel Laureate Rabindranath Tagore praising the land of Bengal as a resplendent mother to all its inhabitants. Remarkably, whether the people are far or near, whether they are communicating with each other or not, they are united by their unflinching spirit of safeguarding the motherland. Such an unflagging devotion is what eventually led to the victory of the Bengalis in December 1971.

The directors' success lies in revivifying this all-pervading emotion. It was a five-year struggle to complete the documentary, for they had to substantiate Levin's footage with other techniques. The cinematic art thus becomes part of the documentary. For example, the close-up of the young Freedom Fighter in Levin's archive has a depth that needed to be established:

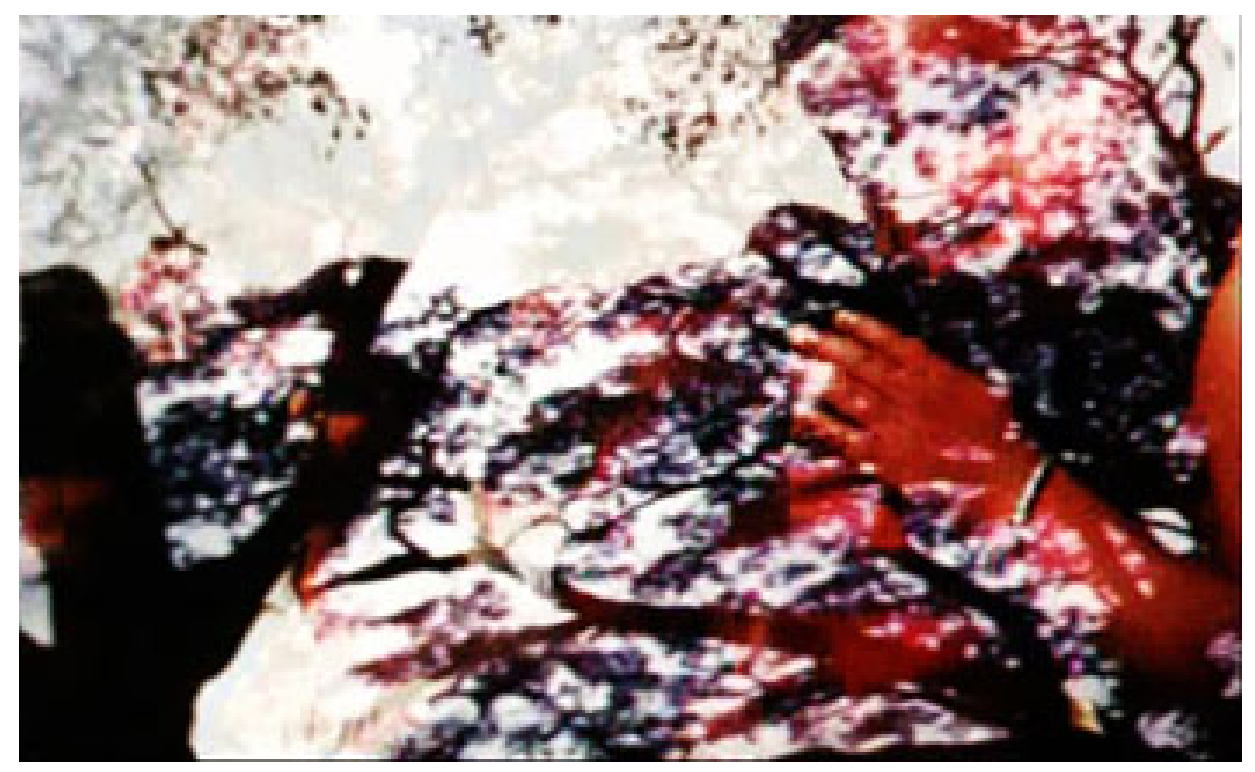

Figure 10: Figure 10

This is why the directors added a context to the face through a news report of All India Radio by Dulal Banerjee. Banerjee's report describes a man called Matiur, who was wounded by the Pakistani army's bombing but pleaded to the attending doctor to 'heal him fast' so that he could return to the battlefield soon. His rural background is evident here. Rather than his social identity, however, what becomes paramount is the fact that he is one of the sons of mother Bengal, who sees his guerrilla activities as a sacred 
duty to her. This is why it does not matter if he was really called Matiur or not, for the Matiurs were numberless in 1971.

Evidently, much thought and effort have gone into the creation of the documentary. The long drawn sound of a classical instrument that introduces its archival nature also interestingly suggests the art working behind it. Therefore, the documentary is not straightforwardly an edited version of the archival footage found in Levin's basement, India, and Britain. In fact, Catharine Masud's account of the creation of the piece reveals the amount of labour, luck and deliberation needed in the process of piecing the disparate footage together. Levin focused on rural Bengal. But the Masuds developed a script that 'required considerable amounts of stock footage on aspects such as genocide, battles, the refugee exodus, and the victory celebration. ${ }^{(15)}$ As a result, there emerges an interesting combination of footage and film, as they incorporated a battle that was recorded separately. 'Over three intensive nights of production this battle was shot, using Freedom Fighters as leaders and trainers and younger boys as extras, ${ }^{(16)}$ reminisces Catherine Masud.

One of the significant results of the Masuds' perfectionism is the way the dialogues are wonderfully woven into the documentary. Tariq Ali's voice over, for example, was never part of Levin's footage. It was integrated into the narrative in order to make the context more intelligible. As a result, the voiceover enhances the two main aspects of the documentary: realism and a youthful spirit. Catherine Masud explains: 'The vehicle of our narration was Tarik Ali, chosen because of his prominence in the footage and because of his naive, lighthearted character that could appeal particularly to young audiences. We adopted a restrained, minimalist style in the narration that would complement rather than direct the images... ${ }^{(17)}$ Ali's youthful voice certainly increases the artistic value of the documentary, for it is complimentary to the accompanying images, rather than obtrusive. It never interrupts moments like the following, when Levin's shot becomes as good as an impressionist painting:

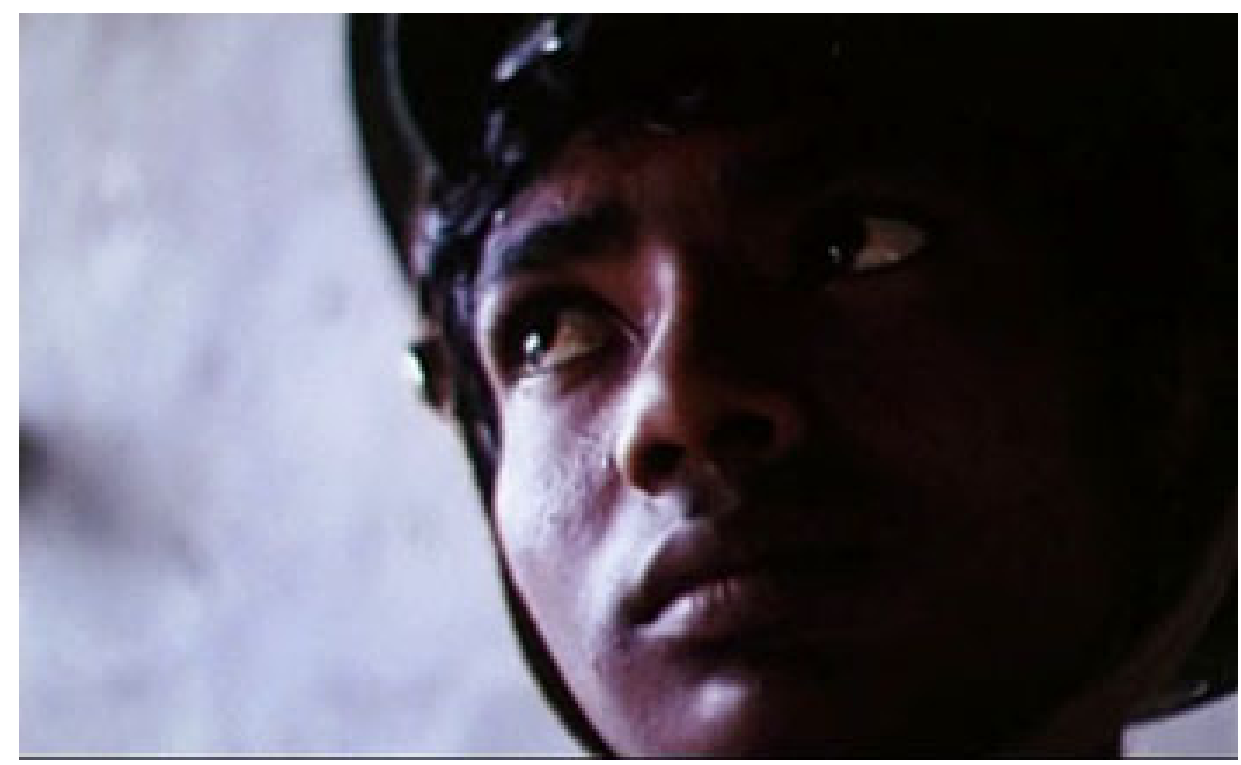

Figure 11: Figure 11

Like Ali's voice, the songs that work as the soul of the documentary were not part of the original footage. However, they never appeared to be extraneous because they 'were known by Tareque to have been part of the troupe's repertoire', states Catherine Masud. ${ }^{(18)}$ Surely, the humanistic ethos of 1971 represented by the songs suggests that history cannot remain 'long forgotten', as the juries at Film South Asia '97 put it. The Bengalis' deep devotion to the motherland is strongly connected to their love for the world. Hence, the song utilized as a refrain in the documentary goes:

Full with riches, rice and flora,

this earth of ours 
......has a country in it -

the best in the world.

Understandably, the Bengalis' pride in the homeland is rooted in their planetary vision. Thus, Tareque \& Catherine Masud's documentary interprets a national struggle for political freedom within a universal and humanist framework. This is why it remains a significant piece of work in the international context as well.

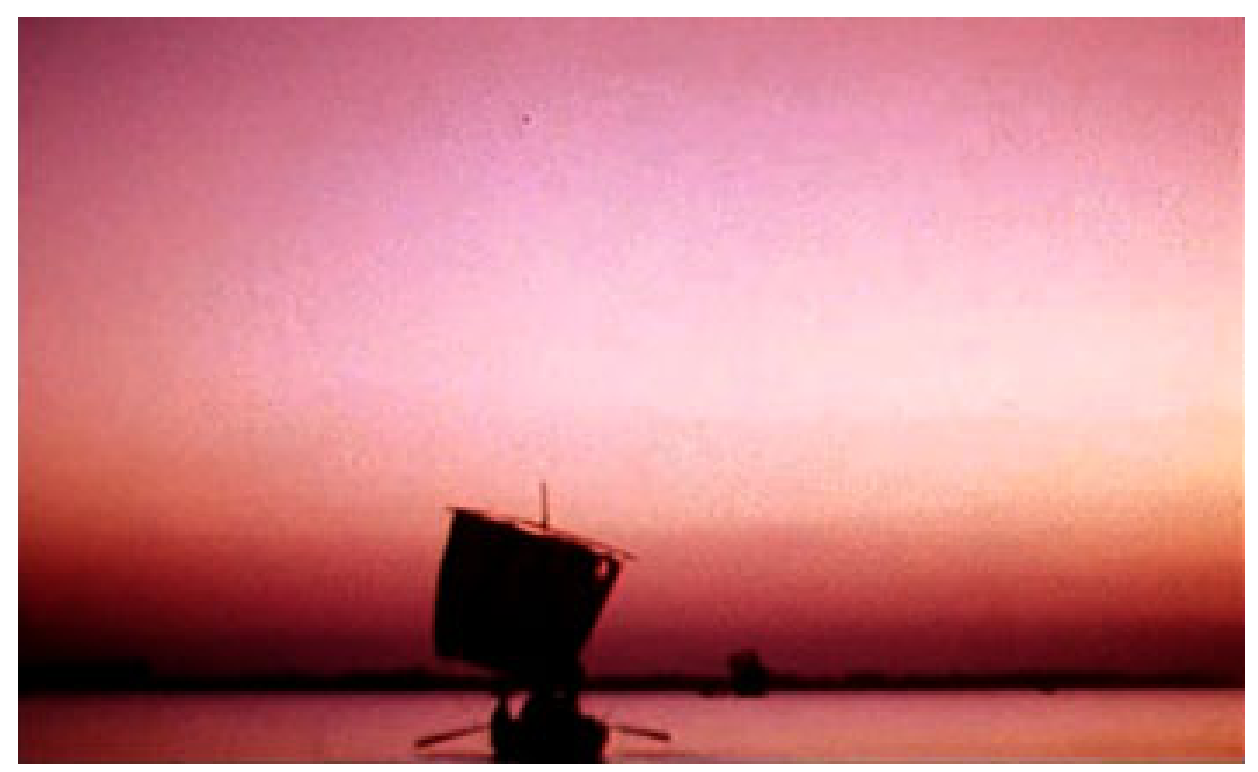

Figure 12: Figure 12

\section{Notes}

1. All images used in the article are the author's collection from the documentary. Muktir Gaan (Song of Freedom), directed by Tareque \& Catherine Masud (1995; Various Places of Bangladesh: Audiovision, 2012 DVD). Catherine Masud's copyright permission to include the images in this article is gratefully acknowledged.

2. Clay Bird won the International Critics' Award (Fipresci) at the Cannes film Festival in 2002. Muktir Gaan received a Special Mention at the South Asian Film festival in 1997.

3. Himal South Asian report, "The Jury Statement," December 1997, http://www.himalmag.com/component/content/article The-Jury-Statement.html.

4. All the dialogues, songs and voice overs quoted in the piece are transcribed from the subtitles of the documentary.

5. Naeem Mohaiemen, "Muktir Gaan: An End to Revisionist History," Forum (A Monthly Publication of The Daily Star), September 2011, http://www.thedailystar.net/forum/2011/September/gaan.htm.

6. Ibid.

7. Ibid.

8. Ibid.

9. Chhetria Patrakar, "Tit Bits from South Asian Region," Himal South Asian, January 2007, http://www.himalmag.com/component/content/article/1137-Tit-bits-from-South Asian-region.html.

10. Nayanika Mookherjee, "Gendered Embodiments: Mapping the Body-Politic of the Raped Woman and 
the Nation in Bangladesh," Feminist Review 88, no.1 (2008): 36-53.

11. Ibid.

12. Mitu Varma, "Historical Perspective: Films in Search of a Movement," Himal South Asian, December 1997, http://www.himalmag.com/component/content/article/2745-Historical-Perspective--Films-inSearch-of-a-Movement.html.

13. Mookherjee, op. cit.

14. Leo Kuper, Genocide: Its Political Use in the Twentieth Century (New Haven, CT: Yale University Press, 1981), 78.

15. Catherine Masud, "The Making of Muktir Gaan," Forum (A Monthly Publication of The Daily Star), March 2008, http://www.thedailystar.net/forum/2008/march/making.htm.

16. Ibid.

17. Ibid.

18. Ibid.

\section{Author Information}

Rehnuma SAZZAD is in her final year of a PhD in Literary and Cultural Studies at Nottingham Trent University. Ms Sazzad's current research focuses on Edward Said and prominent Middle Eastern Arab American intellectuals. 